\title{
ВІЗУАЛЬНА ІНСТАЛЯЦІЯ ЯК ЕЛЕМЕНТ АКТОРСЬКОÏ МАЙСТЕРНОСТІ
}

\author{
Володимир Саган ${ }^{1 a}$, Олег Артамонов ${ }^{2 b}$ \\ ${ }^{1}$ заслужений працівник культури України, доцент; \\ e-mail: vladimirsagan5@gmail.com; ORCID: 0000-0002-5870-935X \\ ${ }^{2}$ магістр; e-mail: olegarta@gmail.com; ORCID: 0000-0002-1842-5109 \\ а комунальний заклад «Одеський театрально-художній коледж», Одеса, Україна \\ ь Луганська державна академія культури і мистецтв, Київ, Україна
}

\section{Анотація}

Мета дослідження - проаналізувати особливості використання форм візуальної інсталяції як важливої складової акторської майстерності. Методологія дослідження. Для досягнення мети використано методи компаративістики як засобу порівняння форм візуальної інсталяції та моделювання ознак елементів, якими ці форми структуровані. Наукова новизна полягає в тому, що схарактеризовано роль та значення форм візуальної інсталяції у процесах акторського виховання, розглянуто також динаміку розвитку методик, які ґрунтуються на використанні візуальної інсталяції як елементу акторської майстерності. Висновки. Візуальна інсталяція - елемент акторської майстерності в процесі створення сценічного образу. Про наявність проблем візуальної інсталяції говорили видатні режисери, актори та викладачі світового рівня. Виховання пластичної виразності у професійних акторів є обов'язковим складником професійної підготовки сучасного актора та необхідним засобом сценічного втілення художнього образу. Наявність різних методик підготовки дає змогу широко використовувати візуальну інсталяцію у роботі актора над роллю в різних режисерських парадигмах, якими представлений розвиток сучасного театрального мистецтва. Розглянуті методики використання візуальної інсталяції в роботі актора розкривають певні тенденції, суть яких полягає в пошуках додаткових засобів виразності у традиційних акторських техніках жестово-поведінкового характеру, намаганні поєднати їх з художніми завданнями, закладеними в "театральний текст», поглибити в його прочитанні смислову багатовекторність через центральну постать сценічної дії - актора. Саме тому зростає вагомість багатополярності в професійній підготовці тих, хто бере участь у створенні вистави. Мова йде про необхідність володіння різними техніками візуальної інсталяції не тільки на акторському рівні, а й на режисерському. Загальна роль цих технік - збагатити сценічну палітру вистави через мову тіла, жестів, рухів, які в сучасному театрі набувають значення провідного виразного засобу, що диктує вибір інших засобів, пов'язаних безпосередньо з учасниками вистави (художнє оформлення, просторове оформлення сцени тощо).

Ключові слова: візуальне мистецтво; інсталяція; акторська майстерність 


\section{Постановка проблеми}

Сучасне театральне мистецтво свідомо заперечує більшість правил та обмежень, демонструє особливе бачення і прагнення до синтезу, йому властивий пошук універсальної художньої мови, зближення та поєднання різноманітних художніх напрямів.

З'являються нові форми театрального мистецтва, зокрема, у сучасній Україні дуже популярною стає пластична драма, або пластична вистава, яка зайняла свою нішу між драматичним мистецтвом, мистецтвом пантоміми та хореографії, але все ж таки є жанром чи формою драматичного мистецтва, де сюжетна лінія залишається подієвою, проте словесна дія або мінімальна, або замінена жестами, позами чи особливими мізансценами.

Кожна форма чи жанр потребує своєрідного підходу. Візуальні інсталяції у практиці акторської майстерності, пластичні засоби виразності збільшилися в палітрі інструментарію, де актуальними тенденціями вважають різножанровість та еклектичність прийомів утілення образу на сцені, який актор вибудовує незалежно від характеристики персонажа в будь-якому літературному творі, а підпорядковуючись жанру та формі, головне, задуму сценічного видовища, зокрема надзавданню вистави та її образному рішенню.

Особливо актуальною у цьому контексті є проблема формування пластичної культури в умовах професійної театральної освіти, яка спонукає дослідити новітні тенденції в характеристиках ролі та значення форм візуальної інсталяції. Цей процес і зумовлює мету статті, що полягає у визначенні форм та динаміки розвитку методик візуальної інсталяції як елементу акторської майстерності.

\section{Аналіз останніх одосліджень і публікацій}

Пластична культура, мова тіла поєднують усі жанри візуального мистецтва. Про це свідчить аналіз напрацьованих під час театрально-педагогічної практики підходів, які зафіксовані в дослідженнях К. С. Станіславського (2017), Є. Б. Вахтангова (1959), Всеволода Меєргольда (1968), О. Я. Таїрова (2018), М. О. Чехова (2018), Леся Курбаса (2001), Є. Ґротовського (2003) тощо.

Беручи до уваги теоретичні здобутки світової театральної педагогіки, варто закцентувати й на працях відомих викладачів театральних дисциплін А. Б. Немеровського (1987), І. Е. Коха (2010), Б. Г. Голубовського (1986), І. Чаббак (2013). Утім, у контексті нашої роботи їхня різноспрямованість вимагає певних теоретичних узагальнень і порівняльного аналізу.

\section{Виклад основного матеріалу}

Відомо, що театр існує в просторі та часі. Ці характеристики ретранслює дія та їі втілювач - актор. Це посилює актуальність його роботи над своєю пластикою. Саме цей аспект акторської діяльності змістовно віддзеркалює термін «візуальна інсталяція», який передбачає ступінь рухової виразності актора, зовнішню і вну- 
трішню, його почуття простору сцени та використання форм, скорельованих на це почуття. Саме тому ця проблема була завжди актуальною в підготовці актора до його професійної діяльності.

Спроби наукового обґрунтування значущості пластичної виразності акторської гри пов'язані з розвитком реалістичного театру, а саме з діяльністю К. С. Станіславського та В. І. Немировича-Данченка.

У контексті практичної підготовки актора, говорячи про пластичну виразність актора, К. С. Станіславський (2017) у «Роботі актора над собою» наголошував, що актор лише тоді перебуває у «формі», коли необхідність бути точним і виразним надиктована творчою діяльністю театру, в якому він працює. Пластична виразність актора залежить від ідейного, пластичного та ритмічного рішення вистави. Саме тому актори маловиразні в тих театрах, де режисура, вирішуючи творчі завдання, володіє, головним чином, словесною дією.

У розділі «Робота актора над собою у творчому процесі переживання» К. С. Станіславський (2017, с.25) підкреслював: «Нам потрібні міцні, сильні, розвинені, пропорційні тіла, гарно складені тіла, без зайвих надлишків. Нехай гімнастика виправляє, а не спотворює їх».

К. С. Станіславський $(2017$, с.23-44) вважав, що опанування низкою навичок пластичної виразності є необхідною передумовою для вирішення творчих завдань, і все ж таки зазначав, що водночас, незважаючи на технічну підготовку (ритміку, гнучкість, спортивність тощо), можна бути пластично невиразним. Актор повинен не тільки займатися фізичною підготовкою та вчитися техніці, хоча це надзвичайно важливо, а й духовно розвиватися, щоб тіло виражало істину актора-образу, його дійсну сутність.

Для В. І. Немировича-Данченка способом візуальної інсталяції актора на сцені $€$ фізичні мізансцени тіла. Він стверджував, що першочергова необхідність - це визначення фізичного самопочуття ролі в будь-якому відрізку, через фізичне самопочуття актор шукає пластику, відчуття тіла, віку, професії, стану здоров'я, настрою, а без правильно знайденого та втіленого фізичного самопочуття роль збіднюється, а актора тягне до штампів, до формальності. Фізичне об'єднується з емоційним і $є$ базою для створення образу, дає основу для психофізичного малюнку ролі (Немирович-Данченко, 1952).

Пластична виразність актора може оцінюватися з погляду аналітичної динаміки руху, виразної моторики тіла, що містять у собі експресію, композиційно-просторове чуття, міру, смак і ще багато іншого.

На відміну від К. С. Станіславського та В. І. Немировича-Данченка, Всеволод Меєргольд не визнавав метод гри «нутром», метод «переживання». Обидва ці методи він вважав небезпечними для психофізики актора, оскільки вони потребують постійного допінгу, «наркозу», і протиставив їм свій метод гри - «біомеханічний».

Всеволод Меєргольд вважав, що театр не витримує нерухливості, завжди поспішає та визнає тільки сучасність, тому театральний актор не повинен грати бездумно, а бути актуальним, здатним за допомогою емоцій заразити глядача.

Біомеханіка як складова театральної системи Всеволода Меєргольда є специфічною формою акторського тренінгу, який надає акторові можливість, без- 
межно використовувати матеріал, в якому він з'являється перед публікою, власне тіло.

М. О. Чехов, за системою якого працюють акторські школи Голлівуду і понині, вважав, що актор повинен правдиво перевтілюватися у своїх персонажів, а не просто перебувати в запропонованому образі, як у К. С. Станіславського. На думку М. О. Чехова, уява - це здатність моментально вжитися в роль, правдиво передати думки, характер та переживання свого героя.

Якщо К. С. Станіславський, учитель М. О. Чехова, не вимагав від акторів, щоб вони позбавлялися своєї індивідуальності, а шукали в собі риси, схожі з рисами персонажа, та пристосовувалися до ситуації і засвоювали простір - у М. О. Чехова (2018) була мета навчити актора виконувати поставлене завдання так, як би це зробив персонаж, використовуючи пози, міміку, ритм та звички героя. Стверджуючи, що «у русі народжується образ та справжні почуття», М. О. Чехов (2018) велику увагу приділяв зовнішній характерності актора-образу, наголошуючи на провідній ролі артиста, хоча і під пильним керівництвом режисера. Для М. О. Чехова уява та фантазія, втілені в образі, мають основні критерії для оцінки драматичного актора як окремої творчої одиниці.

Цікавим є пошук мови тіла, чим займався австрійський вчений, філософ-містик, окультист, письменник, езотерик, соціальний реформатор, архітектор, засновник антропософії Рудольф Штайнер (1894), який винайшов новий підхід до артистичної мови. Він назвав його мистецтвом евритмії, де кожному аспекту мови (звукам (або фонемам), ритмам) відповідає певний архетип, рух або жест, граматичним функціям відповідають душевні якості (радість, відчай, ніжність тощо), і кожному аспекту музики - тони, інтервали, ритми та гармонія.

М. О. Чехов розширив цей метод, який був представлений у його роботі «Про техніку актора».

На відміну від К. С. Станіславського, котрий наголошував на «перевтіленні», на психологічному уподібненні, і на відміну від Всеволода Меєргольда, котрий відсилає актора до «біомеханіки», Лесь Курбас (2001), видатний український режисер, шукає акторську формулу у витках життя, у струменях енергії як такої, у ритмі як основі вітальності, як свідченні глибинних форм життя - органічного і неорганічного. «Все на світі має ритм. І стіл... і моя мова, і вітер, і не тільки ритм для вуха, звуковий, але ритм просторовий (звук - це також простір)», - наполягав Лесь Курбас.

На думку Леся Курбаса (2001), формула актора - «уміння тривати в наміченому уявою ритмі». Проводячи акторські тренажі, український режисер звертався до евритмії Рудольфа Штайнера, використовував ритмопластику Поля Гогена і Вінсента ван Гога, яку вивчали в театрі Леся Курбаса. Приділяючи велику увагу пластиці та виразним засобам через тіло актора, режисер вдавався навіть до тибетської системи медитацій, заснованої на ритмах добування асоціацій із підсвідомості.

$€$. Ґротовський (2003), польський режисер, викладач і теоретик театру, говорив: «У тіла немає пам'яті, воно само - пам'ять». Освоївши «біомеханіку» Всеволода Меєргольда, ознайомившись з «тілесним» підходом, переосмисливши вахтанговський синтез та агресивні виразні засоби і східні театральні прийоми, які 
Bulletin of Kyiv National University of Culture and Arts.

Series in Stage Art

прийняті в пекінській опері, індійському катхакалі та японському театрі Но, він поглибив дослідження праць Ф. Дельсарта, «естетична гімнастика» якого лягла в основу програми першої акторської школи в Америці. Спираючись на методику Ф. Дельсарта, Є. Ґротовський зміг пов'язати всі ці фізичні вправи з більш глибоким розумінням людської природи. Метод польського режисера охоплював інтелектуальність, суворий контроль над тілом, соціальність та містицизм. Створивши концепцію «бідного театру», Є. Ґротовський (2003) сповідав ідею ансамблевої гри та перетворення акторської майстерності з ремесла на мистецтво. Його метод вимагав посиленої фізичної підготовки, ідеального володіння власним тілом, розвитку вокальних навичок.

$€$. Ґротовський створив складну систему акторських тренінгів з постановки дихання, розвитку пластики тіла. Його актори займалися за програмою гімнастів і акробатів, досягаючи віртуозного володіння власним тілом, але головною метою був не холодний професіоналізм, а глибока сповідальність акторського існування - на межі людських можливостей. Завдання методу - розкрити та «роздягти» психіку до підсвідомості. Є. Ґротовський (2003) вважав, що за допомогою тренажів можливо «позбавитися у творчому процесі опору та перепон, які виникають у власному організмі, як психічних, так і фізичних». Є. Ґротовський наполягав, що індивідуальність актора, безумовно, треба розвивати, але розвиток цієї індивідуальності насамперед пов'язаний з позбавленням старих звичок та штампів.

Багато видатних режисерів, викладачів і теоретиків театру, кожен свого часу, приділяли велику увагу пошукам пластичної виразності актора в роботі над сценічним образом. Серед них А. Арто, Е. Піскатор, Є. Вахтангов, М. Рейнгардт, О. Таїров та багато інших; особливо треба відзначити й драматургів періоду виникнення театру абсурду, зокрема Е. Йонеско та С. Бекета, у п'єсах яких важливу роль відіграють акторські ремарки з вказівками, як саме треба грати той чи той образ, наполягаючи на зовнішньому боці втілення образу-персонажа, його зовнішньої характерності.

З часів виникнення професійної театральної освіти на теренах вітчизняної вищої школи є багато праць викладачів театральних дисциплін, зокрема сценічного руху, сценічної пластики, акторської майстерності, які присвячені питанню виховання пластичної культури майбутніх акторів. Такими працями є книги та методики видатного театрального педагога І. Е. Коха (2010), зокрема «Основи сценічного руху», основоположника сценічного руху як дисципліни; «Пластика в мистецтві актора» театрального режисера та педагога Б. Г. Голубовського (1986); «Пластична виразність актора» видатного педагога, актора А. Б. Немеровського (1987) та ін.

І. Е. Кох (2010) у праці «Основи сценічного руху» зазначав: «Спостереження показали, що правильна пластична поведінка в ролі потребує не тільки загальної фізичної підготовки, а й спеціальних рухових навичок. Опанування цими навичками у свою чергу було неможливим без спеціальної підготовки психофізичних якостей». Саме так, писав I. Е. Кох, почала формуватися сутність вимог, необхідних для професії актора з дисципліни сценічного руху. Викладач акцентував на тому, що дієва підготовка майбутнього актора може бути правильно направленою за 
Вісник Київського національного університету культури і мистецтв.

Серія: Сценічне мистецтво

умов розуміння педагогом природи самого сценічного руху, тобто руху, який робить обумовленим фізичну поведінку актора в ролі.

Необхідність удосконалювати дієву підготовку акторів, зазначав педагог, потребує максимального наближення до вимог професії, а отже, одним з найголовніших завдань у цій площині є проблема перенесення навичок та вмінь, отриманих під час тренажів зі сценічного руху та пластики, до драматичного мистецтва. І. Е. Кох $(2010$, c.2) зазначав: «Студенти, які опанували навички танцю, фехтування, жонглювання, акробатики, вміють битися, падати, носити одне одного, мають великий та необхідний комплекс навичок, на жаль, за рідкісними винятками, не використовували ці вміння та навички на заняттях з акторської майстерності. Увесь величезний резерв навичок, отриманих на заняттях з руху, залишався пасивним до тієї пори, поки учні чи актори практично не використовували те чи інше вміння чи навичку в пластичній характерності образу». Педагог наголошував, що перенесення навичок та вмінь, набутих на тренувальних заняттях, у життєву і, головним чином, сценічну практику завжди було складним для акторів, театральних діячів. Саме тому в К. С. Станіславського та Всеволода Меєргольда виникла ідея створити предмет, який дав би змогу вирішити саме це завдання дієвого виховання. Саме цим і пояснюється виникнення занять, які за своїм задумом мають стати проміжною ланкою між виключно тренувальними дисциплінами (акробатикою, жонглюванням, гімнастикою, різними видами спорту) і драматичним мистецтвом.

Завдання підручника І. Е. Коха «Основи сценічного руху» (2010) - розкрити на основі педагогічного та творчого досвіду можливості предмета як засобу удосконалення дієвої культури. Відповідно автор ставить такі цілі:

1. Проаналізувати поняття «дієва культура».

2. Визначити педагогічні завдання в удосконаленні дієвої культури за тими розділами програми, яких немає в заняттях з ритміки, танцю, сценічного фехтування та з фізичної підготовки.

3. Викласти зміст предмета «Основи сценічного руху»: а) визначити загальну мету та педагогічні завдання; б) описати техніку вправ та їх методики; в) описати загальну методику предмета, методику типового уроку, планування навчального матеріалу, принципи критеріїв оцінювання результатів підготовки учнів; г) дати типові музичні приклади до вправ.

На нашу думку, підручник І. Е. Коха, безумовно, є ґрунтовною працею, навчальним посібником та методичною розробкою, яка допомагає опанувати не тільки техніку пластичної виразності, а й взагалі дієву культуру, що необхідна акторові у створенні сценічного образу.

Праця видатного педагога, актора А. Б. Немеровського (1987) «Пластична виразність актора» $є$ узагальненням досвіду його п'ятдесятилітньої педагогічної та режисерської роботи. Автор наголошує про необхідність у роботі над сценічним образом відбору конкретних, найбільш виразних фізичних дій, рухів та мізансцен, жестів, які б найточніше розкривали сутність образу.

Досвід і дослідження автора призвели до висновку, що чим більш оснащений актор у царині руху, ритму, форми, тим більше виразних засобів буде в його артистичній палітрі. Уява, імпровізація, художній смак та всебічна техніка актора, 
Bulletin of Kyiv National University of Culture and Arts

Series in Stage Art

злиті в єдине ціле, народжують неповторні знахідки у пластичній виразності сценічного образу.

А. Б. Немеровський акцентував на тому, що бачення талановитого актора, який не володіє виразним рухом, дією та ритмом, по-перше, здебільшого бувають літературними, тобто недоступними сценічному втіленню. А по-друге, якщо вони й сценічні, то переважно залишаються в уяві актора, бо у нього не вистачає техніки для реалізації, іноді через це не знаходять яскравого втілення цікаві режисерські рішення.

Педагог зазначав, що актору недостатньо лише слова для всебічного розкриття ролі. Позбавляючи своє тіло виразності, актор значно збіднює створюваний образ, обираючи статичні положення тіла, яке боїться рухів та дій, бо володіння ним акторові не притаманне. Але й тут актора спіткає складність, адже він, обираючи мізансцени, під час яких можна не рухатись, навіть всупереч запропонованим обставинам ролі, не має порятунку, - статичні положення вимагають більшої виразності. На відміну від актора, який володіє своїм тілом, досягає яскравості рухів, дій і жестів, у нього значно ширший простір творчої фантазії, оскільки в його свідомості виникає образ, наділений конкретно - індивідуальними пластичними якостями (Немеровский, 1987; Немирович-Данченко, 1952)

Цікавим та важливим, на наш погляд, у методиці А. Б. Немеровського (1987) $€$ цикл вправ з опанування виразними пластичними засобами тіла в поєднанні зі сценічним словом. Проводячи необхідні тренажі, актор у такий спосіб досягає необхідної мети - яскравості та влучності сценічного мовлення, що, безумовно, спільно із зовнішньою та психологічною характерністю призводить до органічності й виразності сценічного образу.

В Україні широковідомі практики та системи вітчизняних викладачів, режисерів і акторів, які працюють на ниві театральної освіти. Це, зокрема, народний артист України В. Абазопуло, Н. Майборода, А. Маслов-Лисичкін, О. Гончаров та ін.

За останні роки цікавими є практики викладачів акторської майстерності світового рівня, які провідне місце відводять роботі актора над пластичною виразною культурою тіла, візуальною інсталяцією в роботі над образом. Тут слід згадати праці І. Чаббак «Майстерність актора: Техніка Чаббак» (2013), Ю. Альшица «Тренінг Forever!» (2009) тощо.

У книзі І. Чаббак, знаменитої викладачки акторської майстерності, «Майстерність актора. Техніка Чаббак» висвітлено унікальну акторську техніку, яка відкрила шлях до вершин Голлівуду багатьом акторам. Опираючись на засади системи К. С. Станіславського, авторка проводить дослідження у сфері розуміння особистих переживань як невід'ємної частини процесу акторської гри. І. Чаббак $(2013$, с.9) зазначає, що будь-який персонаж має мету, потребує щось, жадає чогось досягти (кохання, влади, визнання, слави), і сюжет демонструє нам, як саме він намагається одержати бажане. На думку автора, саме це прагнення - суть конфлікту. Перемагаючи, вони визначають свою поведінку. Яскраві та енергійні люди прагнуть до втілення своїх бажань так само яскраво й енергійно, вкладаючи в це багато сил та емоцій. Актори це роблять свідомо, маючи аналіз своєї ролі, щоб мати природний вигляд, демонструючи яскраву поведінку, саме це і визначає успіх та виразність образу. 
Вісник Київського національного університету культури і мистецтв.

Серія: Сценічне мистецтво

Викладач зазначає дванадцять кроків (інструментів) для створення яскравого образу: 1) надзавдання; 2) сценічне завдання; 3) перепони; 4) заміна; 5) внутрішні об’єкти; 6) такти та дії в такт; 7) передісторія; 8) місце дії та четверта стіна; 9) маніпуляції; 10) внутрішній монолог; 11) життєві обставини; 12) будь, що буде (Чаббак, 2013, с.12-14).

І. Чаббак наголошує, що інструменти можуть допомогти актору вжитися в образ персонажа, а не просто показати його; акторські інструменти - це засоби для досягнення мети, а не сама мета, усе це дасть змогу проявити істинну сутність актора.

Зазначаючи важливість пластичної виразності образу у виявленні його через зовнішню характерність, авторка наголошує на тому, що успішніший актор той, хто, на думку режисера чи продюсера, зміг додати фізичний, поведінковий елемент.

3 проведеного аналізу акторської техніки І. Чаббак можемо зробити такі висновки: для успішної професійної кар'єри актора необхідні такі риси й навички, як зосередженість, упертість, цілеспрямованість, любов до своєї справи, свобода досліджувати та робити відкриття, віра в себе, відточування техніки, уміння ризикувати, готовність навчатися далі, щоденна праця.

Цікавими та корисними є дослідження режисера, викладача та актора Ю. Альшица, викладені в книзі «Тренінг Forever!» (2009). Даючи практичні рекомендації з виконання вправ, етюдів і тренажів з акторської майстерності, автор зазначає, що тренінг - не просто технологічно обов'язковий етап навчання, не муштра, бо це заборонено у вихованні актора, а головний засіб професійного існування та мислення.

Вправи, етюди та тренінгові завдання педагога містять в собі відпрацювання і розвиток психофізичної дії виконавця, внутрішнього відчуття своєї природи через пізнання власного тіла у просторі, свідомої дії в ансамблевості. Автор наголошує, що тренінг - це перехід від одного часу та простору до іншого. Це найважливіший та найскладніший етап перебудови не тільки рефлексів, а й навіть інстинктів людини, зміни природи почуттів, емоцій і поглядів. Тренінг - це зміна системи оцінок, які використовуємо в повсякденному житті, на систему, яку використовуємо на сцені.

Ю. Альшиц чітко не розмежовує фізичне та психологічне існування актора на сцені, наполягає на відкритті психофізики через дослідження об'єктивного простору, тобто через погляд з боку одночасно зі свідомим вольовим актом у фізичному світі. Отож, виконавець постійно перебуває в активній позиції через свої дії як щодо власних внутрішніх переживань, так і до зовнішнього світу. Автор акцентує на практичній цінності таких тренінгів, наводячи приклади зі своєї практики, наголошуючи на їх ефективності та заразливості, адже вправа має не тільки вчити, щось відкрити в індивідуальності, а й заразити бажанням удосконалюватися та працювати над собою.

Отже, Ю. Альшиц зробив такий висновок, що потрібний взаємозв'язок вправ, які поступово ускладнюючись становлять систему роботи актора над собою; кінцева мета та смисл тренінгу - це виховання з актора-виконавця - Артиста, з людини Художника.

Наукова новизна полягає в тому, що схарактеризовано ролі та значення форм візуальної інсталяції у процесах акторського виховання, розглянуто також динаміку розвитку методик, які ґрунтуються на використанні візуальної інсталяції як елементу акторської майстерності. 


\section{Висновки}

Підсумовуючи вищезазначене, можемо зробити висновок, що проблему візуальної інсталяції як елементу акторської майстерності в процесі створення сценічного образу порушували видатні режисери, актори та викладачі світового рівня. Зокрема, як наголошено в статті, усі вони акцентували на тому, що така підготовка є обов'язковою складовою професійної підготовки сучасного актора та необхідним засобом сценічного втілення художнього образу. Наявність різних методик такої підготовки дає змогу широко використовувати візуальну інсталяцію у роботі актора над роллю в різних режисерських парадигмах, якими представлений розвиток сучасного театрального мистецтва.

Розглянуті методики використання візуальної інсталяції в роботі актора розкривають певні тенденції, суть яких полягає в пошуках додаткових засобів виразності у традиційних акторських техніках жестово-поведінкового характеру, намаганнях зв'язати їх з художніми завданнями, закладеними в "театральний текст», поглибити в його прочитанні смислову багатовекторність через центральну постать сценічної дії - актора. Саме тому зростає вагомість багатополярності в професійній підготовці тих, хто бере участь у створенні вистави. Мова йде про необхідність володіння різними техніками візуальної інсталяції не тільки на акторському рівні, а й на режисерському. Загальна роль цих технік - збагатити сценічну палітру вистави через мову тіла, жестів, рухів, які в сучасному театрі набувають значення провідного виразного засобу, що диктує вибір інших засобів, пов'язаних безпосередньо з учасниками вистави (художнє оформлення, просторове оформлення сцени тощо).

Професійна підготовка театральних митців вимагає ширшого впровадження сучасних технік візуальної інсталяції в процес формування акторської та режисерської майстерності, а також детальнішого ознайомлення з ними тих, хто забезпечує підготовку вистави в цілому (художників, костюмерів, музикантів різних спеціальностей, хореографів), що потребує розробки відповідних навчальних програм різного освітнього рівня.

\section{СПИСОК ПОСИЛАНЬ}

Альшиц, Ю.Л., 2009. Тренинг Forever! Санкт-Петербург: ГИТИС.

Арто, А., 2000. Театр и его двойник: Манифесты. Драматургия. Лекции. Философия театра. Санкт-Петербург: Симпозиум.

Бартоу, А. ред., 2017. Акторська майстерність: американська школа.

Голубовский, Б.Г., 1986. Пластика в искусстве актёра. Москва: Искусство.

Гротовский, Е., 2003. От Бедного театра к искусству-проводнику. Москва: Артист. Режиссер. Театр. Искусство.

Корнієнко, Н., 1998. Постмодернізм як культурний жест (коротка мандрівка). Art-line, 7-8, c.4-7.

Кох, И.Э., 2010. Основы сценического движения. Санкт-Петербург: Лань. [online] Доступно: <https://www.litmir.me/br/?b=133165\&p=1> [Дата обращения 3 января 2020]. 
Курбас, Л., 2001. Філософія театру. Київ: Видавництво Соломії Павличко «Основи»

Мейерхольд, В.Э., 1968. Статьи, письма, речи, беседы. Москва: Искусство, Ч.2. (1917-1939). Немеровский, А.Б., 1987. Пластическая выразительность актёра. Москва: Искусство.

Немирович-Данченко, В.И., 1952. Статьи, речи, беседы, письма. Москва: Искусство.

Піскатор, Е., 1932. Політичний театр. Переклад з німецької мови М. Зерова. Київ: Література і мистецтво. [online] Доступно <https://www.livelib.ru/author/326955-ervin-piskator> [Дата звернення 3 січня 2020].

Симонов, Р.Н., 1959. С Вахтанговым. Москва: Искусство.

Станиславский, К.С., 2017. Система Станиславского. Работа актёра над собой. Москва: T8RUGRAM. Ч. 1.

Станиславский. К.С., 2017. Система Станиславского. Работа актёра над собой. Москва: T8RUGRAM. Ч. 2.

Таиров, А., 2018. Записки режиссера об искусстве театра. Санкт-Петербург: Лань.

Чаббак, И., 2013. Мастерство актера: Техника Чаббак. Москва: Эксмо.

Чехов, М., 2018. О технике актера. Москва: АСТ.

Штайнер, Р., 1894. Философия свободы, [online] Доступно: <https://avidreaders.ru/> [Дата обращения 3 января 2020].

\section{REFERENCES}

Alshitc, lu.L., 2009. Trening Forever! [Forever Training!]. St. Petersburg: GITIS.

Arto, A., 2000. Teatr i ego dvoinik: Manifesty. Dramaturgiia. Lektcii. Filosofiia teatra [Theater and its double: Manifestos. Dramaturgy. Lectures. The theater philosophy]. St. Petersburg: Simpozium. Bartou, A. ed., 2017. Aktorska maisternist: amerykanska shkola [Acting: The American School]. Chabbak, I., 2013. Masterstvo aktera: Tekhnika Chabbak [Mastery of the actor: Chubbak's technique]. Moscow: Eksmo.

Chekhov, M., 2018. O tekhnike aktera [On the technique of the actor]. Moscow: AST.

Golubovskii, B.G., 1986. Plastika v iskusstve aktera [Calisthenics in the art of an actor]. Moscow: Iskusstvo.

Grotovskii, E., 2003. Ot Bednogo teatra k iskusstvu-provodniku [From the Poor Theater to an art guide]. Moscow: Artist. Rezhisser. Teatr.

Kokh, I.E., 2010. Osnovy stcenicheskogo dvizheniia [The basics of the stage movement]. St. Petersburg: Lan. [online] Available at: <https://www.litmir.me/br/?b=133165\&p=1> [Accessed 3 January 2020].

Korniienko, N., 1998. Postmodernizm yak kulturnyi zhest (korotka mandrivka) [Postmodernism as a cultural gesture (short trip)]. Art-line, 7-8, pp.4-7.

Kurbas, L., 2001. Filosofiia teatru [Philosophy of theater]. Kyiv: Vydavnytstvo Solomii Pavlychko "Osnovy".

Meierkhold, V.E., 1968. Stati, pisma, rechi, besedy [Articles, letters, speeches, conversations]. Moscow: Iskusstvo, Ch.2. (1917-1939).

Nemerovskii, A.B., 1987. Plasticheskaia vyrazitelnost aktera [The calisthenics expressiveness of the actor]. Moscow: Iskusstvo.

Nemirovich-Danchenko, V.I., 1952. Stati, rechi, besedy, pisma [Articles, speeches, conversations, letters]. Moscow: Iskusstvo. 
Piskator, E., 1932. Politychnyi teatr [Political theater]. Translated from German by M. Zerov. Kyiv: Literatura i mystetstvo. [online] Available at: <https://www.livelib.ru/author/326955-ervinpiskator> [Accessed 3 January 2020].

Shtainer, R., 1894. Filosofiia svobody [Philosophy of Liberty], [online] Available at: <https:// avidreaders.ru/> [Accessed 3 January 2020].

Simonov, R.N., 1959. S Vakhtangovym [With Vakhtangov]. Moscow: Iskusstvo.

Stanislavskii, K.S., 2013. Rabota aktera nad soboi. Protcess voploshcheniia [The actor's work on himself. The embodiment process]. Moscow: Eksmo.

Stanislavskii, K.S., 2017. Sistema Stanislavskogo. Rabota aktera nad soboi [The Stanislavsky system. The actor's work on himself]. Moscow: T8RUGRAM. Ch. 1.

Stanislavskii. K.S., 2017. Sistema Stanislavskogo. Rabota aktera nad soboi [The Stanislavsky system. The actor's work on himself]. Moscow: T8RUGRAM. Ch. 2.

Tairov, A., 2018. Zapiski rezhissera ob iskusstve teatra [Director's notes on the theater art]. St. Petersburg: Lan.

\title{
ВИЗУАЛЬНАЯ ИНСТАЛЛЯЦИЯ КАК ЭЛЕМЕНТ АКТЕРСКОГО МАСТЕРСТВА
}

\author{
Владимир Саган ${ }^{1 a}$, Олег Артамонов ${ }^{2 b}$ \\ ${ }^{1}$ заслуженный работник культуры Украины, доцент; \\ e-mail: vladimirsagan5@gmail.com; ORCID: 0000-0002-5870-935X \\ ${ }^{2}$ магистр; e-mail: olegarta@gmail.com; ORCID: 0000-0002-1842-5109 \\ ${ }^{\text {a } к о м м у н а л ь н о е ~ у ч р е ж д е н и е ~ « О д е с с к и и ̆ ~ т е а т р а л ь н о-х у д о ж е с т в е н н ы и ̆ ~ к о л л е д ж », ~ О д е с с а, ~ У к р а и н а ~}$ \\ ' Луганская государственная академия культуры и искусств, Киев, Украина
}

\begin{abstract}
Аннотация
Цель исследования - проанализировать особенности использования форм визуальной инсталляции как важной составляющей актерского мастерства. Методология исследования. Для достижения цели использованы методы компаративистики как средства сравнения форм визуальной инсталляции и моделирования признаков элементов, которыми эти формы структурированы. Научная новизна заключается в том, что охарактеризована роль и значения форм визуальной инсталляции в процессах актерского воспитания, рассмотрена также динамика развития методик, основанных на использовании визуальной инсталляции как элемента актерского мастерства. Выводы. Визуальная инсталляция - элемент актерского мастерства в процессе создания сценического образа. О наличии проблем визуальной инсталляции говорили выдающиеся режиссеры, актеры и преподаватели мирового уровня. Воспитание пластической выразительности в профессиональных актеров является обязательным компонентом профессиональной подготовки современного актера и необходимым средством сценического воплощения художественного образа. Наличие различных методик подготовки позволяет широко использовать визуальную инсталляцию в работе актера над ролью в разных режиссерских парадигмах, представляющих развитие
\end{abstract}


современного театрального искусства. Рассмотренные методики использования визуальной инсталляции в работе актера раскрывают определенные тенденции, суть которых заключается в поисках дополнительных средств выразительности в традиционных актерских техниках жестово-поведенческого характера, попытке связать их с художественными задачами, заложенными в «театральный текст», углубить в его прочтении смысловую многовекторность с помощью актера - центральной фигуры сценического действия. Именно поэтому возрастает весомость многополярности в профессиональной подготовке тех, кто участвует в создании спектакля. Речь идет о необходимости владения различными техниками визуальной инсталляции не только на актерском уровне, но и на режиссерском. Общая роль данных техник - обогатить сценическую палитру спектакля используя язык тела, жестов, движений, которые в современном театре приобретают значение ведущего выразительного средства, диктующего выбор других средств, связанных непосредственно с участниками спектакля (художественное оформление, пространственное оформление сцены и т. д.).

Ключевые слова: визуальное искусство; инсталляция; актерское мастерство

\title{
VISUAL INSTALLATION AS AN ACTING ELEMENT
}

\section{Volodymir Sagan ${ }^{1 a}$, Oleg Artamonov ${ }^{2 b}$}

\author{
${ }^{1}$ Honored Worker of Culture of Ukraine, Associate Professor; \\ e-mail: vladimirsagan5@gmail.com; ORCID: 0000-0002-5870-935X \\ ${ }^{2}$ Master; e-mail: olegarta@gmail.com; ORCID: 0000-0002-1842-5109 \\ a the public institution "Odessa Theater and Art College", Odessa, Ukraine \\ ${ }^{b}$ Lugansk State Academy of Culture and Arts, Kyiv, Ukraine
}

\section{Abstract}

The purpose of the research is to analyze the using forms features of visual installation as an important acting component. Research methodology. To achieve the goal, comparative methods have been used as a means of comparing the forms of visual installation and modeling features of the elements by which these forms have been structured. The scientific novelty lies in the fact that the role and values of the forms of visual installation in the processes of acting education have been characterized, and the dynamics of the techniques development based on the use of visual installation as an element of acting is also considered. Conclusions. Visual installation is an element of acting in the process of creating a stage image. Outstanding directors, actors and world-class teachers spoke about the problems of visual installation. The education of calisthenics expressiveness in professional actors is an indispensable component of the professional training of a modern actor and a necessary means of stage embodiment of an artistic image. The presence of various training methods makes it possible to widely use the visual installation in the actor's work on his role in various directorial paradigms representing the modern theater art development. The considered methods of using visual installation in the actor's work reveal certain trends, the essence of which lies in the search for additional means of expression in traditional acting techniques of a gestural and behavioral nature, an attempt to 
connect them with the artistic tasks embedded in the "theater text", and to deepen its semantic vector interpretation with the help of the actor and the central figure of the stage action. That is why the increasing importance of multi polarity in the professional training of those who participate in the creation of the play. We are talking about the need to master various visual installation techniques not only at the acting level, but also at the director's level. The general role of these techniques is to enrich the stage palette of the performance using the language of the body, gestures, movements, which in modern theater acquire the leading means significance of expression, dictating the choice of other means that are directly related to the participants of the performance (decoration, spatial design of the stage, etc.).

Keywords: visual art; installation; acting 